\title{
Doing Business with Business: Municipal Utility Energy Audits
}

\author{
Municipal utilities can use energy audits to identify the energy \\ efficiency measures that are most effective for themselves and their \\ customers.
}

\section{MASTER}

Large or small, any business can benefit from an energy audit. This owner of a New York Life Insurance office in Osage, lowa, reduced his utility bills by $66 \%$ after making improvements recommended by an audit.

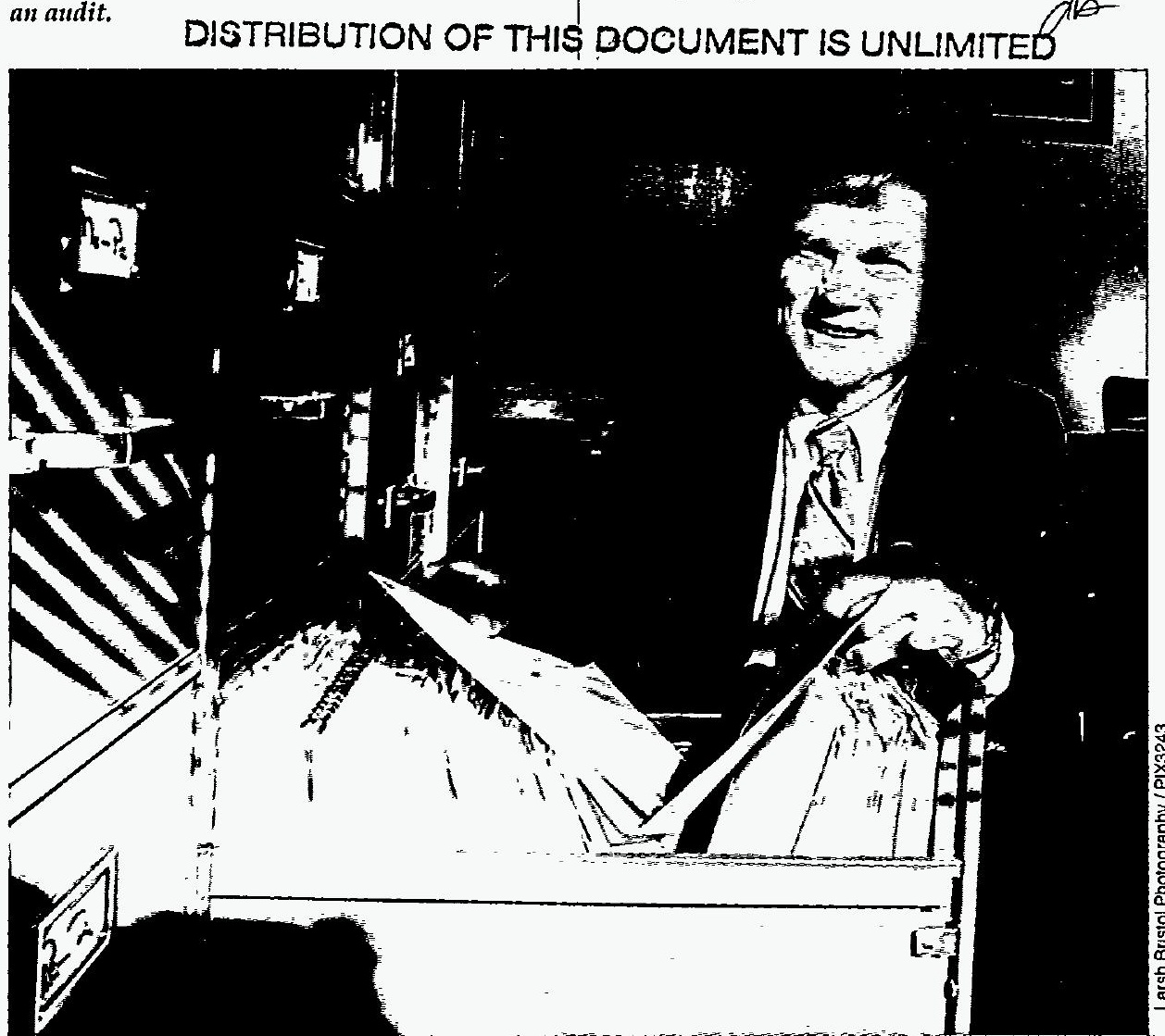

\section{(}

Energy efficiency is a winning proposition for both municipal utilities and their customers. For utilities, promoting efficiency can be less expensive than building power plants. And for business and industry, using energy more efficiently can lower costs and increase profits.

But before you spend money on materials and equipment, it is important to identify the energy efficiency strategies that are most cost effective in a specific situation. An energy audit is a way to gather this information. do

\section{Big Savings for a Small Town in lowa}

In Osage, Iowa, for example, the local utility offers free industrial/commercial audits to local businesses. Osage is a town of about 3500 people located in north-central Iowa. The local municipal utility began a residential energy efficiency program in 1974 and added a commercial and industrial energy efficiency program in 1988. The savings has been substantial.

According to Wes Birdsall, former General Manager of Osage Municipal Utilities (OMU), when both the residential and commercial programs are included, "The Osage project, after 20 years, is saving the city more than $\$ 1$ million per year. The total cost for the 20-year life of the project has been only $\$ 350,000$ ! Any community can realize similar savings," he adds, "but they won't come without work." 
OMU kept the cost of the program this low by distributing materialssuch as flow restrictors, switch and wall socket covers, and insulating blankets for water heaters-free to customers. The customers then installed these items themselves. Low labor cost was a major reason for the low program cost.

During 1988 and 1989, the Osage utility provided free "walk-through" audits by professional engineers to all industrial customers and free follow-up "in-depth" audits when the initial audit identified energy-saving opportunities. The in-depth audits provided managers with estimated costs of the proposed improvements, estimated savings, and simple paybacks-the amount of time necessary to pay for the cost of the improvements in energy savings. The utility also offered to review any plans for plant or process remodeling through its engineering consulting firm, and provided free design recommendations to improve energy efficiency. OMU has conducted walk-through audits on all the industrial customers and most of the commercial businesses in Osage.

For example, one business that took advantage of the free energy audits was $A$ to $Z$ Drying, an agricultural product drying business. $A$ to $Z$ implemented all the measures suggested in the audit that had a payback of 2 years or less. The energy efficiency improvements are now saving the company about $\$ 8,243$ every year.

The audit program has kept rates low because the utility has not had to build new power plants to meet new demand. The low rates have, in turn, attracted industry to the town. One local business, Tops Business Forms, located its facility in Osage in 1984. Darwin Thompson, Plant Manager at Tops, explains, "Our parent company, Wallace Computer Service, had been dealing with the city for
14 years and already owned the property. They were drawn to Osage in part because of the low utility rates." When Tops built the new plant, they incorporated several energy efficiency technologies, including efficient heating and cooling systems, energy-efficient lighting, and computerized thermostat controls.

As a plant manager, Thompson appreciates the utility's willingness to help businesses optimize energy efficiency on an ongoing basis. He says, "Every year we sit down with OMU to review and update the energy efficiency of the plant in light of new technology." These industrial visits are a way to monitor ongoing needs, according to Dennis Fannin, general manager of the utility. "If we find needs, then we address them," Fannin says.

Storefront businesses in Osage also benefited from the free energy audits. A local accounting firm reduced its utility bills by $75 \%$, and a New York Life Insurance office reduced its bills $66 \%$ by implementing energy efficiency improvements identified in the audits provided by OMU.

\section{The Osage Formula for Success}

One ingredient that successful energy efficiency programs have in common is one or more committed individuals who are willing to spread the word about the benefits of saving energy. In Osage, the "energy" behind the energy efficiency program was Birdsall.

The utility has reaped considerable benefits from its energy efficiency programs. In 1972, OMU was about $\$ 1$ million in the red. By 1992, when Birdsall retired, OMU was more than $\$ 4$ million in the black, much of which is now being used to upgrade the electric distribution and generation. This is because of the growth 
In general, customers earn a rebate on the upper end of the range if they own their facility (or have a long lease), if they operate equipment for most of the day (including the peak hours of 1:00 p.m. to 9:00 p.m.), and if they submit a modestly priced retrofit proposal.

Customers may also qualify for $8.5 \%$ financing from SMUD. Any measure that SMUD determines to be cost effective and eligible for a rebate will also be eligible for financing. In some cases, combining the rebates and the loan results in no initial costs for the customer. SMUD offers leasepurchases to public schools and agencies at the same $8.5 \%$ rate.

SMUD also provides assistance to its customers who participate in the energy efficiency program by maintaining a list of qualified contractors, and even assists customers in securing bids. Watanabe attributes the success of the program in part to the utility's relationship with local contractors. He says, "Members of the contracting community are our allies-it's like having 10 times our staff working to attract attention to the program. Contractors bring us $50 \%$ of our customers."

The energy efficiency projects generated by the audits can be very attractive to participating customers. Many of these projects have simple paybacks of less than 2 years when the utility rebate is included in the calculation. For example, after an energy audit at the Bel Air Market in Carmichael, California, the company implemented the measures the auditors identified. The result is a savings of $\$ 21,260$ a year on a project that cost only $\$ 38,901$ after the utility rebate (of $\$ 24,037$ ), for a payback of 1.8 years.

The project included replacing existing lighting with energy-efficient lighting, installing an energy management system and occupancy sensors for controlling lighting, and installing variable-speed drives on 2- to 5-horsepower motors used on air-handling equipment.

In another impressive retrofit project, SMUD audited the Raley's/Bel Air Distribution Center and suggested improvements totaling $\$ 194,533$. As a result of the upgrades, the company saves $\$ 67,490$ annually, for a payback of 2.0 years when the utility rebate of $\$ 58,114$ is included in the analysis.

\section{Free Resource for Conserving Energy and Profits}

One resource that cities and counties can use to work with their local businesses is the Industrial Assessment Center (IAC) program sponsored by the U.S. Department of Energy. Trained auditors from a regional IAC will analyze, for free, industrial plants' energy consumption, waste generation, and manufacturing operations, and recommend ways to run plants more efficiently. IACs are located nationwide. If you're interested in working with your community's local industries to cut energy costs and improve productivity, see For More Information for contact details.

\section{The Bottom Line}

Energy efficiency programs are an important way that utilities save money and improve service to their customers. Energy audits, a key part of these programs, reveal opportunities to use energy more efficiently. When local businesses participate, both they and the utility save money, and the money stays in the local economy. Doing business with business is an attractive economic opportunity for the utility, its customers, and their community.

\section{For More Information}

Dennis Fannin

Osage Municipal Utilities

P.O. Box 207

Osage, IA 50461

(515) 732-3731

Mr. Fannin is the current General Manager of Osage Municipal Utilities.

\section{Wes Birdsall}

RR2, Box 195

Osage, IA 50461

(515) $732-4435$

Mr. Birdsall is responsible for instituting the residential and commercial energy efficiency programs at Osage Municipal Utilities.

\section{Clifton Lewis}

Sacramento Municipal Utility District Commercial/Industrial Retrofit Services

6507 4th Avenue, Suite 500

Sacramento, CA 95817

(916) 732-6619

\section{Skip Laitner}

Economic Research Associates

1205 Collingwood Road, Suite 100

Alexandria, VA 22308-1729

(703) 780-6407

EconSkp@aol.com.

$\mathrm{Mr}$. Laitner can provide more information about economic multipliers.

Industrial Assessment Center

Office of Industrial Productivity and

Energy Assessment

Rutgers University

P.O. Box 1179

Piscataway, NJ 08854

(908) 445-3655

Energy Efficiency and Renewable Energy Clearinghouse

P.O. Box 3048

Merrifield, VA 22116

(800) 363-3732

EREC, funded by the U.S. Department of Energy, provides information on renewable energy and energy efficiency technologies.

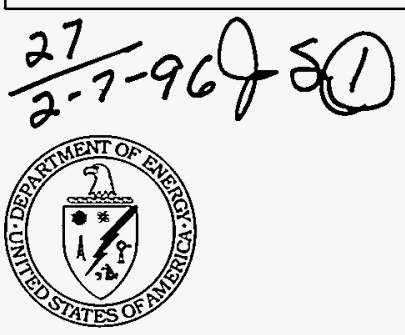

This document was produced for the U.S. Department of Energy (DOE) by the National Renewable Energy Laboratory, a DOE national laboratory. The document was produced by the Technical Information Program, under the DOE Office of Energy Efficiency and Renewable Energy.

\section{DOE/GO-10095-211}

DE95013110

December 1995 